\title{
Cancer screening recommendations: an international comparison of high income countries
}

\author{
Mark H. Ebell ${ }^{1 *}$ (D, Thuy Nhu Thai ${ }^{2}$ and Kyle J. Royalty ${ }^{3}$
}

\author{
* Correspondence: ebell@uga.edu \\ ${ }^{1}$ College of Public Health, University \\ of Georgia, 125 Miller Hall, UGA \\ Health Sciences, GA 30602 Athens, \\ Georgia, USA \\ Full list of author information is \\ available at the end of the article
}

\begin{abstract}
Background: Recommendations regarding cancer screening vary from country to country, and may also vary within countries depending on the organization making the recommendations. The goal of this study was to summarize the cancer screening recommendations from the 21 countries with the highest per capita spending on healthcare.

Main body: Cancer screening guidelines were identified for each country based on a review of the medical literature, internet searches, and contact with key informants in most countries. The highest level recommendation was identified for each country, in the order of national recommendation, cancer society recommendation, or medical specialty society recommendation. Breast cancer screening recommendations were generally consistent across countries, most commonly recommending mammography biennially from ages 50 to 69 or 70 years. In the USA, specialty societies generally offered more intensive screening recommendations. All countries also recommend cervical cancer screening, although there is some heterogeneity regarding the test (cytology or HPV or both) and the age of initiation and screening interval. Most countries recommend colorectal cancer screening using fecal immunochemical (FIT) testing, while only seven countries recommend general or selective screening for prostate cancer, and a similar number explicitly recommend against screening for prostate cancer. Screening for lung and skin cancer is only recommended by a few countries. Greater per capita healthcare expenditures are not associated with greater screening intensity, with the possible exception of prostate cancer.
\end{abstract}

Conclusions: Guidelines for cancer screening differ between countries, with areas of commonality but also clear differences. Recommendations have important commonalities for well-established cancer screening programs such as breast and cervical cancer, with greater variation between countries regarding prostate, colorectal, lung, and skin cancer screening. Ideally, recommendations should be made by a professionally diverse, independent panel of experts that make evidence-based recommendations regarding screening based on the benefits, harms, and available resources in that country's context.

Keywords: Cancer screening, Breast cancer, Colorectal cancer, Prostate cancer, Cervical cancer, Overdiagnosis, Healthcare economics, Lung cancer, Skin cancer

\section{Biomed Central}

(c) The Author(s). 2018 Open Access This article is distributed under the terms of the Creative Commons Attribution 4.0 International License (http://creativecommons.org/licenses/by/4.0/), which permits unrestricted use, distribution, and reproduction in any medium, provided you give appropriate credit to the original author(s) and the source, provide a link to the Creative Commons license, and indicate if changes were made. The Creative Commons Public Domain Dedication waiver (http://creativecommons.org/ publicdomain/zero/1.0/) applies to the data made available in this article, unless otherwise stated. 


\section{Background}

Cancer is the second leading cause of death worldwide [1], with 8.8 million cancer deaths in 2015 [1], and over 14 million new cancer cases diagnosed in 2012 [2]. About $30 \%$ of cancer deaths occurred in high-income countries [1]. Cancer screening programs have the potential to reduce cancer-specific and possibly all-cause mortality $[3,4]$. The United States Preventive Services Task Force (USPSTF) has concluded that there is at least adequate evidence of a net benefit for screening for lung, breast, cervical, and colorectal cancers [5-8], and screening programs for cancer are widespread in other high resource countries [3, 4, 9-11]. For example, of over 31 million women eligible for breast cancer screening in European countries, 79\% were invited to screen and $49 \%$ were screened [3]. Breast cancer mortality has decreased in the USA from 31.4 to 20.5 deaths per 100,000 women between 1975 and 2014, with similar trends in Europe, an effect attributable to both screening and improved treatment [12].

Cancer screening programs have largely been implemented in high-income countries with greater available resources $[9,13,14]$. However, there is considerable variation in terms of screening methods, starting age, stopping age, and screening interval between countries $[3,4,9]$. For example, the USPSTF recommends that adults aged 50 to 75 years should be screened for colorectal cancer with one of seven tests or combinations of tests (including colonoscopy), [8] while the Canadian Task Force on Preventive Health Care does not recommend colonoscopy as a screening test [15]. In Europe, even after the European Union recommendations in 2003, the implementation of the Council recommendations differs between countries [3]. We hypothesize that countries spending more on healthcare per capita will have more intensive cancer screening recommendations, screening for more cancers over a longer age range, and at a shorter screening interval (Appendix).

In the current report, we will review and compare cancer screening recommendations implemented in 21 high resource countries that in 2015 spent at least $\$ 3000$ per capita on healthcare. We will review national recommendations where available, or the most relevant other guidelines for that country where national or federal recommendations such as those of the USPSTF do not exist. The cancers addressed will include breast, cervical, colorectal, prostate, skin, and lung cancer. As a point of comparison with US national guidelines from the USPSTF, we include relevant specialty society guidelines from the American College of Radiology, American College of Obstetrics and Gynecology, and others.

\section{Methods}

The goal of the study was to compare cancer screening recommendations in countries with comparable levels of healthcare spending, and to try to understand the relationship between healthcare spending and the intensity of screening recommendations. Membership in the Organization for Economic Cooperation and Development (OECD) was chosen as the initial qualification for inclusion in the study to ensure that the countries compared were similar economically. It was then decided that total health expenditure per capita was the most relevant statistic to national cancer screening recommendations. Therefore, the 35 OECD member countries were rank ordered according to total healthcare expenditure per capita using data from 2015. From this ranked list, all countries that spent over USD3000 per capita on health that year were included $(n=21)$ [16]. 
The next step was to determine which national organization's cancer screening guidelines would be chosen as that country's national recommendations. First, colleagues of the authors in each country of the study were consulted as local content experts. This was supplemented by searches of the internet where necessary. Once the national recommendations were determined for each country, the data were abstracted in tandem by two members of the research team, consulting with the project leader (Dr. Ebell) to resolve any discrepancies.

To create a uniform grading scheme, each screening test for each type of cancer was graded as recommended (which includes both strongly recommended and recommended), recommended selectively, recommended against, or insufficient evidence, corresponding to the categories used by the US Preventive Services Task Force. After analysis of each country's national screening recommendations, the data were organized into tables. Finally, screening intensity was defined for breast, cervical, and colorectal cancer as the total number of lifetime screening tests recommended for an average risk person.

\section{Results}

Information for the organizations making screening recommendations is shown in Table 1. We abstracted the screening's recommendations from national guideline committee's websites for 15 out of the 21 selected countries. The other countries' recommendations are from cancer society's websites. Notably, for the USA, beside the United Stated Preventive Services Task Force (USPSTF), we additionally abstracted the recommendations from the American Cancer Society (since it is widely used by US physicians) and three specialty society's websites.

\section{Breast cancer screening}

The recommendations for breast cancer screening with mammography are presented in Table 2. Overall, the recommendations for breast cancer are quite similar among the 21 selected countries. The most common screening age ranges are from 50 to 69 years old, and most of those countries are European. Screening for breast cancer every 2 years is recommended in most of the countries. Only Japan does not specify the screening interval. The American College of Radiology has the longest age range for screening and is the only guideline in the world recommending an annual screening interval, while the United Kingdom has the longest screening interval (every 3 years).

\section{Cervical cancer screening}

Table 3 describes cervical cancer screening's recommendations. Luxembourg is the only country with no national recommendation identified for cervical cancer screening. There was some heterogeneity regarding the recommended tests (cytology, HPV, or both), the age to begin screening, and screening intervals. Most countries recommend an age of initiation of screening from 18 to 29 years and a stopping age between 60 and 70 years. Countries most commonly recommend a screening interval of 3 to 5 years. Six out of the 21 countries have adopted HPV testing as a primary test for cervical cancer screening, and cytology is still predominantly recommended with a screening interval of 3 years.

\section{Colorectal cancer screening}

Table 4 demonstrates the variability in screening recommendations across different countries with respect to both the type and schedule of screening. Even within the USA 
Table 1 Organizations making screening recommendations, by country

\begin{tabular}{|c|c|c|}
\hline Country & Organization Name & Type of organization \\
\hline United States & United States Preventive Services Task Force & National guideline committee \\
\hline United States & American Cancer Society & Cancer society \\
\hline United States & American College of Obstetrics \& Gynecology & Specialty society \\
\hline United States & American College of Radiology & Specialty society \\
\hline United States & American Urological Association & Specialty society \\
\hline Luxembourg & Ministry of Health & National guideline committee \\
\hline Switzerland & League Against Cancer & Cancer society \\
\hline Norway & Cancer Registry of Norway & Cancer society \\
\hline Netherlands & National Institute for Public Health and the Environment & National guideline committee \\
\hline Germany & Federal Joint Committee & National guideline committee \\
\hline Sweden & National Board of Health and Welfare & National guideline committee \\
\hline Ireland & National Screening Service & National guideline committee \\
\hline Austria & Austrian Cancer Aid Society & Cancer society \\
\hline Denmark & National Board of Health & National guideline committee \\
\hline Belgium & Foundation Against Cancer & Cancer society \\
\hline Canada & Canadian Task Force for Preventive Health Care & National guideline committee \\
\hline Australia & Australian Government Department of Health & National guideline committee \\
\hline France & National Cancer Institute & National guideline committee \\
\hline Japan & National Cancer Center & National guideline committee \\
\hline Iceland & Icelandic Cancer Society & Cancer society \\
\hline United Kingdom & United Kingdom National Screening Committee & National guideline committee \\
\hline Finland & Cancer Society of Finland & Cancer society \\
\hline New Zealand & Ministry of Health & National guideline committee \\
\hline Italy & National Screening Observatory & National guideline committee \\
\hline Spain & Cancer Strategy of National Health System & National guideline committee \\
\hline
\end{tabular}

differences in guidelines exist, as the USPSTF and American Cancer Society (ACS) express no preference concerning the type of test, while the recent joint recommendations from several specialty societies recommend a tiered approach with colonoscopy or fecal immunochemical (FIT) testing offered first [17]. All other countries recommend a test for fecal occult blood, colonoscopy, or either. Regarding fecal occult blood testing, FIT is generally preferred over gFOBT, especially in more recent guidelines. Concerning the use of colonoscopy as a screening method, the only countries outside the USA that recommend it are Switzerland, Germany, and Austria. In some countries, the infrastructure may be lacking in terms of the number of trained gastroenterologists to support this screening method, although cost and acceptability are also important factors. The results summarized in Table 4 reflect no clear association between total healthcare expenditure per capita and colorectal cancer screening recommendations, other than that 4 of 5 countries recommending the shortest screening interval are among the lowest spenders per capita. Notably, only Austria and Japan recommend initiation of screening for average risk persons at age 40.

\section{Prostate cancer screening}

Table 5 demonstrates the variability between various countries regarding screening for prostate cancer. Unlike that with the other cancers, the chief disagreement concerning prostate cancer is not between the type and frequency of test but rather whether or not 
Table 2 Recommendations for breast cancer screening with mammography, in order of overall healthcare spending

\begin{tabular}{|c|c|c|c|c|c|c|c|c|c|c|}
\hline Country & Organization (Type) & Year & $40-44$ & $45-49$ & 50-54 & $55-59$ & $60-64$ & $65-69$ & 70-74 & $75+$ \\
\hline United States & US Preventive Services Task Force (A) & 2016 & & & & & & & & \\
\hline United States & American Cancer Society (B) & 2015 & & & & & & & & \\
\hline United States $^{1}$ & American College of Obstetrics \& Gynecology (C) & 2017 & & & & & & & & \\
\hline United States & American College of Radiology (C) & 2016 & & & & & & & & \\
\hline Luxembourg & Ministry of Health $(A)$ & NA & & & & & & & & \\
\hline Switzerland $^{2}$ & League Against Cancer (B) & 2016 & & & & & & & & \\
\hline Norway & Cancer Registry of Norway (B) & 2010 & & & & & & & & \\
\hline Netherlands $^{3}$ & NIPHE (A) & 2017 & & & & & & & & \\
\hline Germany & Federal Joint Committee (A) & 2015 & & & & & & & & \\
\hline Sweden ${ }^{4}$ & National Board of Health and Welfare (A) & 2013 & & & & & & & & \\
\hline Ireland & National Screening Service (A) & NA & & & & & & & & \\
\hline Austria & Austrian Cancer Aid Society (B) & 2014 & & & & & & & & \\
\hline Denmark & National Board of Health $(\mathrm{A})$ & 2014 & & & & & & & & \\
\hline Belgium & Foundation Against Cancer (B) & 2017 & & & & & & & & \\
\hline Canada $^{5}$ & CTFPHC (A) & 2011 & & & & & & & & \\
\hline Australia & Australian Government Department of Health (A) & 2015 & & & & & & & & \\
\hline France $^{6}$ & National Cancer Institute (A) & 2015 & & & & & & & & \\
\hline $\operatorname{Japan}^{7}$ & National Cancer Center $(\mathrm{A})$ & 2016 & & & & & & & & \\
\hline Iceland & Icelandic Cancer Society (B) & NA & & & & & & & & \\
\hline UK & UK National Screening Committee $(\mathrm{A})$ & 2012 & & & & & & & & \\
\hline Finland & Cancer Society of Finland (B) & 2010 & & & & & & & & \\
\hline New Zealand & Ministry of Health (B) & 2014 & & & & & & & & \\
\hline Italy & National Screening Observatory $(\mathrm{A})$ & 2015 & & & & & & & & \\
\hline Spain & Cancer Strategy of National Health System (A) & 2009 & & & & & & & & \\
\hline Recommend: & Recommend selectively: & & not rec & nmend & & & Insufficie & t eviden & & \\
\hline Every 3 years: & Every 2 years: & & Eve & 1 year: & & & & & & \\
\hline
\end{tabular}

Type of organization: $A$ national guideline committee, $B$ cancer society, $C$ specialty society, $D$ other

${ }^{1}$ United States American College of Obstetrics and Gynecology: screening interval of 1 or 2 years

${ }^{2}$ Switzerland: screening age of $50-70$ years

${ }^{3}$ Netherlands: screening age of $50-75$ years

${ }^{4}$ Sweden: screening interval is 18 months from age 40 to 54 years

${ }^{5}$ Canada: screening interval of 2 or 3 years

${ }^{6}$ France: screening age of $50-75$ years

${ }^{7}$ Japan: Do not recommend a screening interval

Abbreviations: UK United Kingdom, USA United States of America, NIPHE National Institute for Public Health and the

Environment, CTFPHC Canadian Task Force on Preventive Health Care, NA not available (cannot find information)

${ }^{*}$ Consider the person's life expectancy when making a decision

to screen at all. In fact, if one includes the current 2012 USPSTF recommendation, eight countries explicitly recommend against prostate cancer screening. Of the remaining countries that did not recommend against screening, the vast majority did not have an organized national screening program in place, recommended that an individual consult with their physician or did not make a recommendation.

\section{Skin cancer screening}

Most countries included did not make a recommendation regarding skin cancer screening. Only the USA, Germany, Austria, and France address skin cancer screening. The latter three recommend screening, while the USPSTF has determined that there is insufficient evidence to recommend visual skin examination by a physician. Germany recommends that such examination take place every 2 years beginning at age 35, and France provides seven questions for general practitioners to ask their patients in order to assess risk. Uniquely, Austria recommends self-examination and recommends doing so twice a year (before and after the summer months). None of the countries recommending screening provide an age to stop screening.

\section{Lung cancer screening}

Among 21 selected countries, only 5 countries have recommendations regarding lung cancer screening (USA, Canada, Japan, United Kingdom, and Australia). Australia and the United Kingdom recommend against lung cancer screening. Both the USPSTF and 
Table 3 Recommendations for cervical cancer screening, in order of overall healthcare spending

\begin{tabular}{|c|c|c|c|c|c|c|c|c|c|c|}
\hline Country & Organization (Type) & $\begin{array}{l}\text { Year } \\
\end{array}$ & Test & 10-19 & 20-29 & 30-39 & $40-49$ & $50-59$ & 60-69 & 70-79 \\
\hline United States $^{1}$ & US Preventive Services Task Force (A) & 2012 & Cyt & & & & & & & \\
\hline United States $^{1}$ & US Preventive Services Task Force (A) & 2012 & Cyt+HPV & & & & & & & \\
\hline United States $^{1}$ & US Preventive Services Task Force draft (A) & 2017 & Cyt & & & & & & & \\
\hline United States $^{1}$ & US Preventive Services Task Force draft (A) & 2017 & HPV & & & & & & & \\
\hline United States $^{1}$ & American Cancer Society (B) & 2016 & Cyt. & & & & & & & \\
\hline United States $^{1}$ & American Cancer Society (B) & 2016 & Cyt+HPV & & & & & & & \\
\hline United States $^{1}$ & American College of Obstetrics \& Gynecology & 2016 & Cyt. & & & & & & & \\
\hline United States $^{1}$ & American College of Obstetrics \& Gynecology & 2016 & Cyt+HPV & & & & & & & \\
\hline Luxembourg & Ministry of Health (A) & & & & & & & & & \\
\hline Switzerland $^{2}$ & League Against Cancer (B) & 2010 & Cyt & & & & & & & \\
\hline Norway $^{3}$ & Cancer Registry of Norway (B) & 2010 & Cyt & & & & & & & \\
\hline Norway $^{3}$ & Cancer Registry of Norway (B) & 2010 & HPV & & & & & & & \\
\hline Netherlands ${ }^{4}$ & NIPHE (A) & 2015 & Cyt & & & & & & & \\
\hline Germany $^{5}$ & Federal Joint Committee (A) & 2015 & Cyt & & & & & & & \\
\hline Sweden ${ }^{6}$ & National Board of Health and Welfare (A) & 2014 & Cyt & & & & & & & \\
\hline Sweden $^{6}$ & National Board of Health and Welfare (A) & 2014 & HPV & & & & & & & \\
\hline Ireland ${ }^{7}$ & National Screening Service (A) & 2009 & Cyt & & & & & & & \\
\hline Austria $^{8}$ & Austrian Cancer Aid Society (B) & NR & Cyt & & & & & & & \\
\hline Denmark $^{9}$ & National Board of Health (A) & 2014 & Cyt & & & & & & & \\
\hline Denmark $^{9}$ & National Board of Health (A) & 2014 & HPV & & & & & & & \\
\hline Belgium $^{10}$ & Foundation Against Cancer (B) & 2017 & Cyt & & & & & & & \\
\hline Canada & CTFPHC (A) & 2013 & Cyt & & & & & & & \\
\hline Australia"11 & Australian Government Department of Health (A) & 2017 & Cyt & & & & & & & \\
\hline Australia ${ }^{11}$ & Australian Government Department of Health (A) & 2017 & HPV & & & & & & & \\
\hline France $^{12}$ & National Cancer Institute (A) & 2017 & Cyt & & & & & & & \\
\hline $\operatorname{Japan}^{13}$ & National Cancer Center (A) & 2010 & Cyt & & & & & & & \\
\hline $\operatorname{Japan}^{13}$ & National Cancer Center (A) & 2010 & HPV & & & & & & & \\
\hline $\operatorname{Japan}^{13}$ & National Cancer Center (A) & 2010 & Cyt+HPV & & & & & & & \\
\hline $\operatorname{Japan}^{13}$ & National Cancer Center (A) & 2010 & $\begin{array}{l}\text { HPV with } \\
\text { cyt triage }\end{array}$ & & & & & & & \\
\hline Iceland ${ }^{14}$ & Icelandic Cancer Society (B) & NR & Cyt & & & & & & & \\
\hline $\mathrm{UK}^{15}$ & UKK National Screening Committee (A) & 2016 & HPV & & & & & & & \\
\hline Finland $^{16}$ & Cancer Society of Finland (B) & 2010 & Cyt or HPV & & & & & & & \\
\hline New Zealand ${ }^{17}$ & Ministry of Health (B) & 2014 & Cyt & & & & & & & \\
\hline Italy ${ }^{18}$ & National Screening Observatory (A) & 2015 & Cyt & & & & & & & \\
\hline Spain 19 & Cancer Strategy of National Health System (A) & 2009 & Cyt & & & & & & & \\
\hline Recommend: & Recommend selectively: & \multicolumn{3}{|c|}{ Do not recommend } & & \multicolumn{3}{|c|}{ Insufficient evidence: } & & \\
\hline Every 7 years: & Every 5 years: & & \multicolumn{2}{|c|}{ Every 3 years: } & & & & & & \\
\hline Every 2 years: & Every year: & \multicolumn{3}{|c|}{ No interval specified: } & & & & & & \\
\hline
\end{tabular}

Type of organization: $A$ national guideline committee, $B$ cancer society, $C$ specialty society, $D$ other

Start and stop age coding: wavy border-not specified

Most guidelines recommend that screening cease between ages 65 and 70 years in women with consistently normal

screening in the previous decade. Screening is not recommended for women who have had a hysterectomy for

benign disease

${ }^{1}$ USA: screening age of 21-65 years for cytology and 30-65 years for cytology and HPV testing

${ }^{2}$ Switzerland: start and stop ages are not recommended

${ }^{3}$ Norway: screening age of and 25-69 years for cytology and 34-69 years for HPV testing

${ }^{4}$ Netherlands: screening age of $30-60$ years

${ }^{5}$ Germany: stop age is not recommended

${ }^{6}$ Sweden: screening age of 23-29 years for cytology and 30-64 years for HPV testing

7Ireland: screening age of 25-61 years

${ }^{8}$ Austria: stop age is not recommended

${ }^{9}$ Denmark: screening age of 23-59 years for cytology and 60-64 years for HPV testing

${ }^{10}$ Belgium: screening age of $25-65$ years for cytology

${ }^{11}$ Australia: screening age of 18-69 years for cytology (current recommendation) and 25-75 years for HPV testing (will implement from December 2017)

${ }^{12}$ France: screening age of $25-65$ years

${ }^{13}$ Japan: stop age and screening interval are not recommended

${ }^{14}$ Iceland: screening age of 23-65 years

${ }^{15} \mathrm{UK}$ : screening age of $25-64$ years

${ }^{16}$ Finland: screening age of $30-60$ years

${ }^{17}$ New Zealand: screening age of $20-70$ years

${ }^{18}$ Italy: screening age of 25-64 years (some programs have moved into $25-30 / 35$ years with cytology and 30/35-64 years with HPV testing)

${ }^{19}$ Spain: screening age of $25-65$ years

Abbreviations: USPSTF United States Preventive Services Task Force, NIPHE National Institute for Public Health and the Environment, CTFPHC Canadian Task Force on Preventive Health Care, NA not applicable (cannot find information), Cyt. cytology, Cyt + HPV cytology plus HPV co-testing

+Date website with recommendation last updated

the Canadian Task Force recommend low-dose computed tomography (CT) for smokers with at least 30 pack-year smoking history and who smoke or quit smoking less than 15 years. However, the USPSTF recommends screening for the age range 55 to 80 years, while the Canadian Task Force recommends screening for a narrower age range from 55 to 74 years, with a screening interval of 1 to 3 years. In contrast to the 
Table 4 International colorectal cancer screening recommendations for the general population (persons not at "high-risk"), in order of decreasing total healthcare expenditure per capita

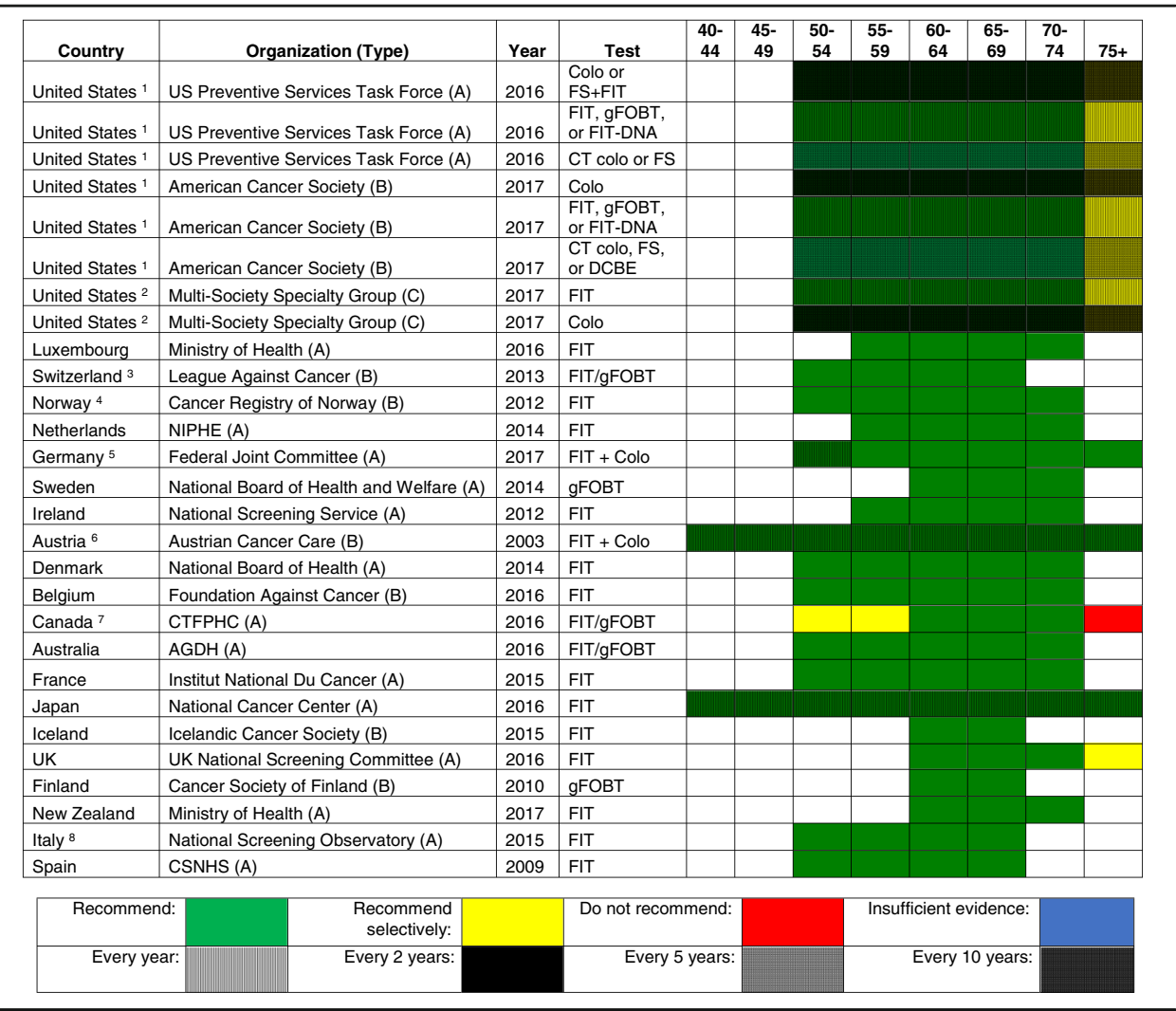

Type of organization: $A$ national guideline committee, $B$ cancer society, $C$ specialty society or societies

${ }^{1}$ USPSTF and ACS: no preference regarding choice of tests; high sensitivity gFOBT preferred, with recommendation against in-office FIT or gFOBT; FIT-DNA is every 1 or 3 years; FS + FIT is FS every 10 years and FIT annually

${ }^{2}$ US Multi-Society Guidelines: consider screening between 75 and 85 if no previous screening

${ }^{3}$ Switzerland: or colonoscopy every 10 years

${ }^{4}$ Norway: currently being compared to flexible sigmoidoscopy (with screening once every 10 years from age 50 to 74 ) in a pilot study

${ }^{5}$ Germany: beginning at age 55, also obtain colonoscopy every 10 years (at a minimum), stopping after 2 colonoscopies

${ }^{6}$ Austria: beginning at age 50 , also obtain colonoscopy every $7-10$ years

${ }^{7}$ Canada: or flexible sigmoidoscopy every 10 years; colonoscopy is not recommended

${ }^{8}$ Italy: FIT or flexible sigmoidoscopy once at age 58 or 60 , and then FIT every 2 years from age 59 to 69 Abbreviations: USA United States of America, Colo colonoscopy, CT colo CT colonography, FIT fecal immunochemical test, gFOBT guaiac fecal occult blood test, NIPHE National Institute for Public Health and the Environment, CTFPHC Canadian Task Force on Preventive Health Care, CSNHS Cancer Strategy of the National Health System, AGDH Australian Government Dept of Health

USA and Canada, Japan recommends chest radiography to screen for lung cancer starting at age 40 years, but concludes that there is insufficient evidence for low-dose CT. Japan does not recommend a stopping age or screening interval. Several European countries have screening trials underway, so these recommendations may change when those results are available $[18,19]$.

\section{Association between healthcare expenditures and screening intensity}

Figure 1 summarizes the relationship between healthcare expenditures and the intensity of screening, measured as the total lifetime number of screening tests recommended for an average risk person for breast, cervical, and colorectal cancer (the latter based on recommendations for use of the FIT). It shows that there is no clear association between expenditures 
Table 5 International prostate cancer screening recommendations for the general population (persons not at "high-risk"), in order of decreasing total healthcare expenditure per capita

\begin{tabular}{|c|c|c|c|c|c|c|c|c|c|c|c|}
\hline Country & Organization (Type) & Year & Test & $\begin{array}{r}40- \\
44\end{array}$ & $\begin{array}{r}45- \\
49\end{array}$ & $\begin{array}{l}50- \\
54\end{array}$ & $\begin{array}{c}55- \\
59\end{array}$ & $\begin{array}{l}60- \\
64\end{array}$ & $\begin{array}{l}65- \\
69\end{array}$ & 70-74 & $75+$ \\
\hline United States & USPSTF final recommendation (A) & 2012 & PSA & & & & & & & & \\
\hline United States & USPSTF draft recommendation (A) & 2017 & PSA & & & & & & & & \\
\hline United States 1 & American Cancer Society (B) & 2016 & PSA & & & & & & & & \\
\hline United States $^{2}$ & American Urological Association (C) & 2015 & PSA & & & & & & & & \\
\hline Luxembourg $^{3}$ & Ministry of Health (A) & 2014 & PSA & & & & & & & & \\
\hline Switzerland ${ }^{4}$ & League Against Cancer (B) & 2015 & DRE, PSA & & & & & & & & \\
\hline Norway & Cancer Registry of Norway (B) & & & & & & & & & & \\
\hline Netherlands & NIPHE (A) & & & & & & & & & & \\
\hline Germany & Federal Joint Committee (A) & 2017 & DRE & & & & & & & & \\
\hline Sweden & NBHW (A) & 2016 & PSA & & & & & & & & \\
\hline Ireland & National Screening Service (A) & & & & & & & & & & \\
\hline Austria $^{5}$ & Austrian Cancer Care (B) & 2015 & DRE, PSA & & & & & & & & \\
\hline Denmark & National Board of Health (A) & & & & & & & & & & \\
\hline Belgium ${ }^{6}$ & Foundation Against Cancer (B) & 2017 & PSA & & & & & & & & \\
\hline Canada & CTFPHC (A) & 2014 & PSA & & & & & & & & \\
\hline Australia & AGDH (A) & 2017 & PSA & & & & & & & & \\
\hline France & Institut National Du Cancer (A) & 2016 & PSA & & & & & & & & \\
\hline Japan & National Cancer Center (A) & 2009 & DRE, PSA & & & & & & & & \\
\hline Iceland ${ }^{7}$ & Icelandic Cancer Society (B) & 2016 & PSA & & & & & & & & \\
\hline United Kingdom & UK National Screening Committee (A) & 2016 & PSA & & & & & & & & \\
\hline Finland & Cancer Society of Finland (B) & & & & & & & & & & \\
\hline New Zealand & Ministry of Health (A) & 2016 & PSA & & & & & & & & \\
\hline Italy & National Screening Observatory (A) & & & & & & & & & & \\
\hline Spain & $\operatorname{CSNHS}(\mathrm{A})$ & 2009 & PSA & & & & & & & & \\
\hline Recommend: & $\begin{array}{r}\text { Recommend } \\
\text { selectively: }\end{array}$ & $\begin{array}{r}\text { Do no } \\
\text { recommend }\end{array}$ & & & $\begin{array}{l}\text { ficient } \\
\text { lence: }\end{array}$ & & & & $\begin{array}{r}\text { nmenc } \\
\text { ave }\end{array}$ & $\begin{array}{l}\text { itions } \\
\text { lable: }\end{array}$ & \\
\hline Every year: & Every 2 years: & $\begin{array}{r}\text { No interve } \\
\text { provided }\end{array}$ & & & & & & & & & \\
\hline
\end{tabular}

Interval coding: vertical cross-hatch every year, solid every 2 years, diagonal line no interval provided

Type of organization: $A$ national guideline committee, $B$ cancer society, $C$ specialty society

${ }^{1}$ US American Cancer Society: screening should be done every year if PSA levels are greater than $2.5 \mathrm{ng} / \mathrm{mL}$; stop screening in asymptomatic men with less than 10 years life expectancy; men at increased risk should consider beginning screening at 40 or 45 years

${ }^{2}$ US American Urological Association: an interval of 2 years or more is preferred. Additionally, baseline PSA levels can be used to individualize rescreening intervals. Screening should be stopped in asymptomatic men whose life expectancy is less than 10 years

${ }^{3}$ Luxembourg: age to start screening not provided. No organized national guidelines; screening based on individual discussion between patient and physician

${ }^{4}$ Switzerland: age to start screening not provided. No organized national guidelines; screening based on individual discussion between patient and physician

${ }^{5}$ Austria: "Screening should be carried out 'regularly' from the 45th birthday"

${ }^{6}$ Belgium: no organized national guidelines; screening based on individual discussion between patient and physician ${ }^{7}$ Iceland: no organized national guidelines; screening based on individual discussion between patient and physician Abbreviations: USPSTF United States Preventive Services Task Force, PSA prostate-specific antigen, NIPHE National Institute for Public Health and the Environment, DRE digital rectal examination, NBHW National Board of Health and Welfare, CTFPHC Canadian Task Force on Preventive Health Care, AGDH Australian Government Department of Health, CSNHS Cancer Strategy of the National Health System

and screening intensity for these cancers, disproving our initial hypothesis. Regarding prostate cancer, 5 of the top 10 countries in terms of healthcare expenditure recommend selective or routine screening, compared with only 2 of the bottom 10 countries. Finally, the three countries recommending lung cancer screening are ranked 1st, 12th, and 15th in spending, again creating no pattern of higher spending equating to higher intensity of screening.

\section{Discussion}

We have summarized national screening recommendations for the 21 countries with the highest total healthcare expenditure per capita. These countries were selected because they are likely to have adequate resources for a cancer screening program of some kind; comparison with less well-resourced settings would be unfair and would be less likely to reflect the differences in values, priorities, and the assessment of evidence that we are interested in. As physicians and researchers in the USA, we are especially interested in how our recommendations compare with other countries, and what we can learn from them. 


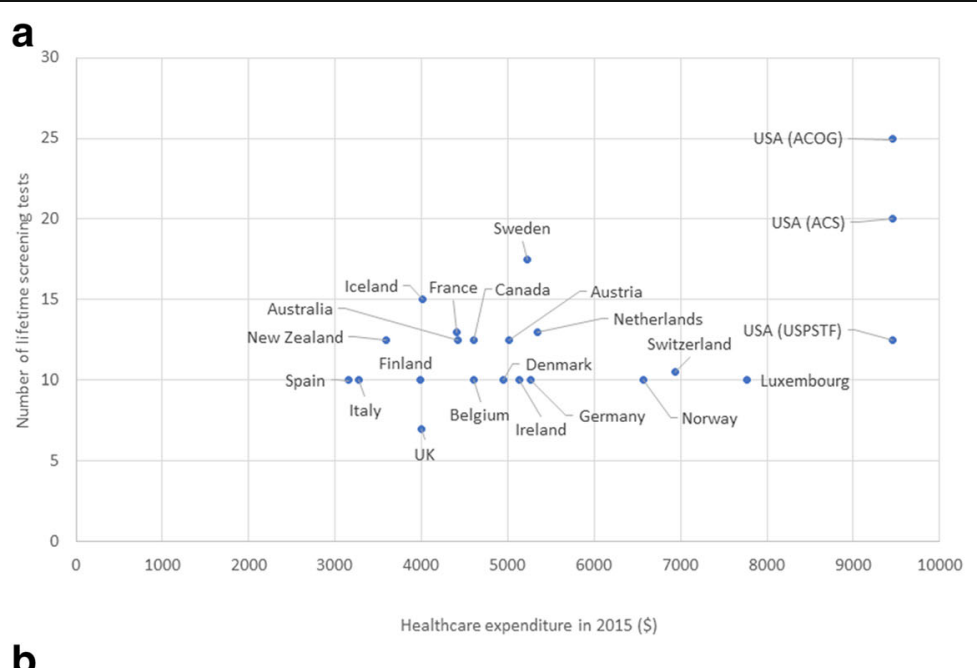

b
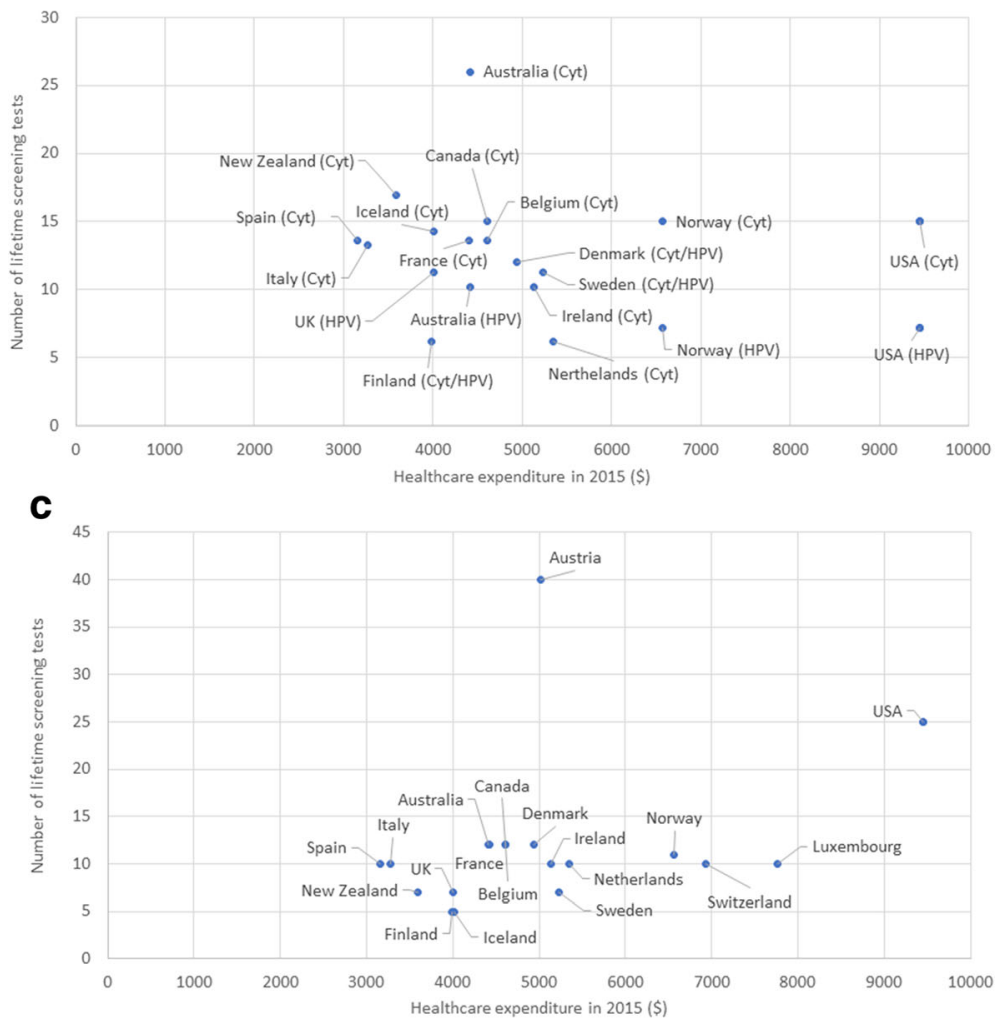

Fig. 1 This figure shows the relationship between per capita spending on healthcare with the number of lifetime screening tests recommended for a) breast cancer (mammography), b) cervical cancer (cytology or HPV), and c) colorectal cancer (FIT)

In comparing recommendations, we are not making value judgements or endorsing a single "correct" answer regarding age at initiation, screening interval, or age at cessation of screening. These decisions likely reflect differences between countries and organizations regarding how benefits and harms are valued and balanced at a societal level, the type of evidence considered, the availability of resources and infrastructure for screening (for example, adequate trained medical personnel to perform colonoscopy), whether and how cost is considered, and different standards for assembling, evaluating, and 
interpreting a complex evidence base. For example, does the body making a recommendation consider only randomized controlled trials with cancer-specific mortality as the outcome, or does it also consider observational data and modeling studies? [20] Does the panel consider outcomes beyond mortality, such as disease progression, cost, stage shifts, or quality of life? Is cost explicitly considered or is the decision made solely on the balance of potential benefits and harms?

Note that in our discussion below, we consider the USPSTF to represent the US national screening recommendation, although recommendations from USA specialty and cancer societies are also presented. Also, when we use the term "more aggressive" or "more conservative" to describe screening recommendations, we refer to recommendations with a broader age range and/or a more frequent interval vs a narrower age range and/or a less frequent interval. Finally, a review of the process used by each country or organization to develop and update guidelines is beyond the scope of this article.

\section{Commonalities}

There was considerable homogeneity regarding screening recommendations for breast cancer, cervical cancer, and to some extent, colorectal cancer. A starting age for routine mammography of 50 years was recommended by 16 of 21 countries; all countries but one recommended a biennial interval, and 14 recommended a stopping age of 69 or 70 years. Similarly, most countries recommended cervical cancer screening beginning between 21 and 30 years of age (depending on whether or not testing for human papillomavirus was employed), and most recommended a stopping age between 65 and 70 years. Similarly, most countries recommended that colorectal cancer screening begin at age 50 or 55 years and stop by 75 years. Finally, there is a general consensus against screening for lung cancer and melanoma, with only the USA, Japan, and Canada recommending lung cancer screening and only Germany, Austria, and France recommend some approach to screening for skin cancer.

\section{Differences}

The approach to screening for cervical cancer is evolving, with some countries still recommending cytology only, some recommending HPV testing or co-testing, and some giving clinicians the option of choosing the favored approach. Four countries (Iceland, UK, Sweden, and Finland) do not recommend screening for colorectal cancer until age 60, compared to start ages between 40 and 50 years for most other countries. The recommended test for colorectal cancer screening also varies. FIT was most widely recommended, while the USPSTF offered seven different options, and Germany and Austria recommended FIT for younger patients followed by a series of colonoscopies. There is considerable heterogeneity regarding prostate cancer screening: seven countries recommend screening for prostate cancer in some form, while eight explicitly recommend against it. This is likely due to variation in how guideline panels assess the potential benefits and harms.

\section{Variation by country and type of organization}

For prostate cancer screening, of the seven countries with a recommendation to screen or screen selectively for prostate cancer, five were from the top half of the selected countries based on per capita health expenditures. Four of the five countries with the 
shortest interval for colorectal cancer screening (Iceland, UK, Finland, and New Zealand) are among the six lowest spending countries. However, there was no apparent association between per capita health expenditures and the intensity of screening for breast and cervical cancer.

Other than within the USA, there was no clear difference in terms of the intensity of screening recommendations coming from national guideline committees, cancer societies or leagues, and specialty societies. In the USA, the recommendations regarding mammography from the American Cancer Society, American College of Obstetrics and Gynecology, and American College of Radiology were the only ones identified that recommended annual screening and also had longer screening intervals for patients at average risk. The American College of Radiology was the only body that recommended annual mammography starting at age 40 years, with no specified stopping age. On the other hand, there is considerable similarity regarding colorectal cancer screening between the USPSTF, ACS, and specialty society guidelines.

Prostate cancer screening recommendations are now similar between the USPSTF draft recommendation of 2017 and the American Urology Association, and recommendations regarding cervical cancer screening between the USPSTF, ACS, and ACOG are nearly identical. Assuming that they are based on the best available evidence, this kind of "harmonization" between guidelines from different groups within a country sends a clear, unified message to patients and physicians. In the absence of such harmonization, confusion may reign and physicians may do what feels right or what is requested by patients rather than what is supported by the best evidence. Due to medicolegal concerns, some physicians may feel compelled to practice based on the most aggressive set of recommendations or based on patient request. This is especially true in the USA context, where "failure to diagnose" is the most common reason for a malpractice lawsuit [21].

\section{Conclusions}

Guidelines for cancer screening differ between countries, with areas of commonality but also clear differences. Per capita healthcare spending among wealthy countries appears to have relatively little impact on recommendations; differences are more likely to stem from variation in how benefit and harm are evaluated, and which evidence is considered. Intellectual and financial conflicts of interest inherent to professional societies may contribute to more aggressive recommendations for breast cancer screening from these groups in the USA. A greater intensity of screening may alter the balance of benefits and harms by increasing the likelihood of direct harms of the screening test, as well as the serious harms associated with overdiagnosis [22]. In some cases, where specialty societies have adopted more rigorous methods, their recommendations have become more conservative, as when the American Urologic Association moved from a consensus to an evidence-based process [23]. Of course, one could also argue that national bodies like the USPSTF or Canadian Task Force are overly conservative since they rely largely on randomized trials and modeling for their recommendations. And, even groups using similarly rigorous methods may reach different conclusions, with USA and Canadian recommendations for colorectal cancer screening a good example.

In conclusion, we encourage the formation of independent panels of experts in each country, modeled after the USPSTF, Canadian Task Force, and the UK National Screening Committee. These panels should make independent, evidence-based recommendations 
regarding screening that assess the benefits, harms, and available resources in that country's context. Consistent with IOM recommendations, the panels should include primary care physicians, patients, methodologic experts and relevant subspecialists, recommendations should be regularly updated, and panel members should be free of financial and intellectual conflict of interest to the greatest extent possible [24].

\section{Appendix}

Table 6 The references of the national recommendations for breast, cervical, colorectal, prostate, skin, and lung cancer screening by country

\begin{tabular}{|c|c|c|}
\hline Country & Reference & $\begin{array}{l}\text { Year of recommendation } \\
\text { or most recent update }\end{array}$ \\
\hline \multicolumn{3}{|l|}{ Breast cancer } \\
\hline United States (USPSTF) & $\begin{array}{l}\text { https://www.uspreventiveservicestask } \\
\text { force.org/Page/Document/Update } \\
\text { SummaryFinal/breast-cancer-screening1 }\end{array}$ & 2016 \\
\hline United States (ACS) & $\begin{array}{l}\text { https://www.cancer.org/cancer/breast- } \\
\text { cancer/screening-tests-and-early- } \\
\text { detection/american-cancer-society- } \\
\text { recommendations-for-the-early-detec } \\
\text { tion-of-breast-cancer.html }\end{array}$ & 2015 \\
\hline United States (ACOG) & $\begin{array}{l}\text { http://www.acog.org/About-ACOG/ } \\
\text { News-Room/Practice-Advisories/ } \\
\text { Practice-Advisory-Breast-Cancer- } \\
\text { Screening }\end{array}$ & 2017 \\
\hline United States (ACR) & $\begin{array}{l}\text { https://www.acr.org/Advocacy-and- } \\
\text { Economics/ACR-Position-Statements/ } \\
\text { Breast-Cancer-Screening-for-Average- } \\
\text { Risk-Women }\end{array}$ & 2017 \\
\hline Luxembourg (Ministry of Health) & $\begin{array}{l}\text { https://plancancer.lu/about/depistage/ } \\
\text { cancer-du-sein/depistage-actuel-cancer- } \\
\text { du-sein/ }\end{array}$ & NA \\
\hline Switzerland (League Against Cancer) & $\begin{array}{l}\text { https://www.liguecancer.ch/prevenir- } \\
\text { le-cancer/depistage-et-prevention- } \\
\text { du-cancer/cancer-du-sein/depistage- } \\
\text { par-mammographie/ } \\
\text { https://www.swisscancerscreening. } \\
\text { ch/fr/cancer-du-sein/informations- } \\
\text { generales/mammographie }\end{array}$ & 2016 \\
\hline Norway (Cancer Registry of Norway) & $\begin{array}{l}\text { https://www.kreftregisteret.no/en/ } \\
\text { screening/Breast-Cancer-Screening- } \\
\text { Programme }\end{array}$ & 2010 \\
\hline Netherlands (NIPHE) & $\begin{array}{l}\text { http://www.rivm.nl/en/Topics/B/ } \\
\text { Breast_cancer_screening_programme }\end{array}$ & 2017 \\
\hline Germany (Federal Joint Committee) & $\begin{array}{l}\text { https://www.g-ba.de/institution/ } \\
\text { themenschwerpunkte/frueher } \\
\text { kennung/krebsfrueherkennung/ }\end{array}$ & 2015 \\
\hline $\begin{array}{l}\text { Sweden (National Board of } \\
\text { Health and Welfare) }\end{array}$ & $\begin{array}{l}\text { http://www.socialstyrelsen.se/riktlinjer/ } \\
\text { nationellascreeningprogram/brost } \\
\text { cancer-screeningmedmammog }\end{array}$ & 2013 \\
\hline Ireland (National Screening Service) & $\begin{array}{l}\text { http://www.screeningservice.ie/ } \\
\text { screening.html }\end{array}$ & NA \\
\hline Austria (Austrian Cancer Aid Society) & $\begin{array}{l}\text { https://www.krebshilfe.net/information/ } \\
\text { krebs-vorsorge/mammografie-screening/ } \\
\text { https://ec.europa.eu/health/sites/ } \\
\text { health/files/major_chronic_diseases/ } \\
\text { docs/2017_cancerscreening_2ndrepor } \\
\text { timplementation_en.pdf }\end{array}$ & 2014 \\
\hline
\end{tabular}


Table 6 The references of the national recommendations for breast, cervical, colorectal, prostate, skin, and lung cancer screening by country (Continued)

\begin{tabular}{|c|c|c|}
\hline Country & Reference & $\begin{array}{l}\text { Year of recommendation } \\
\text { or most recent update }\end{array}$ \\
\hline Denmark (National Board of Health) & $\begin{array}{l}\text { https://www.sst.dk/da/udgivelser/2014/ } \\
\text { 〜/media/31CB15B2A39E4A3EB198B94 } \\
\text { 86F66B4A2.ashx }\end{array}$ & 2014 \\
\hline Belgium (Foundation Against Cancer) & $\begin{array}{l}\text { http://www.cancer.be/les-cancers/ } \\
\text { types-de-cancers/cancer-du-sein/ } \\
\text { examens }\end{array}$ & 2017 \\
\hline Canada (CTFPHC) & $\begin{array}{l}\text { http://canadiantaskforce.ca/guidelines/ } \\
\text { published-guidelines/breast-cancer/ }\end{array}$ & 2011 \\
\hline $\begin{array}{l}\text { Australia (Australian Government } \\
\text { Department of Health) }\end{array}$ & $\begin{array}{l}\text { http://www.cancerscreening.gov.au/ } \\
\text { internet/screening/publishing.nsf/ } \\
\text { Content/breast-screening-1 }\end{array}$ & 2015 \\
\hline France (National Cancer Institute) & $\begin{array}{l}\text { http://www.e-cancer.fr/Professionnels- } \\
\text { de-sante/Depistage-et-detection- } \\
\text { precoce/Depistage-du-cancer-du-sein/ } \\
\text { Orienter-vos-patientes }\end{array}$ & 2015 \\
\hline Japan (National Cancer Center) & $\begin{array}{l}\text { http://canscreen.ncc.go.jp/guideline/ } \\
\text { nyugan.html }\end{array}$ & 2016 \\
\hline Iceland (Icelandic Cancer Society) & $\begin{array}{l}\text { https://www.krabb.is/leitarstod/um- } \\
\text { leitarstodina/af-hverju-brjostakrabbame } \\
\text { insleit/leit-ad-krabbameini-i-brjostum-1 }\end{array}$ & NA \\
\hline UK (UK National Screening Committee) & $\begin{array}{l}\text { https://legacyscreening.phe.org.uk/ } \\
\text { breastcancer } \\
\text { http://www.nhs.uk/Conditions/breast- } \\
\text { cancer-screening/Pages/When-its- } \\
\text { offered.aspx }\end{array}$ & 2012 \\
\hline Finland (Cancer Society of Finland) & $\begin{array}{l}\text { https://www.cancer.fi/syoparekisteri/ } \\
\text { en/mass-screening-registry/breast_ } \\
\text { cancer_screening/screening_programme/ } \\
\text { https://ec.europa.eu/health/sites/ } \\
\text { health/files/major_chronic_diseases/ } \\
\text { docs/2017_cancerscreening_2ndreportim } \\
\text { plementation_en.pdf }\end{array}$ & 2010 \\
\hline New Zealand (Ministry of Health) & $\begin{array}{l}\text { https://www.nsu.govt.nz/breastscreen- } \\
\text { aotearoa/what-breast-cancer }\end{array}$ & 2014 \\
\hline Italy (National Screening Observatory) & $\begin{array}{l}\text { http://www.osservatorionazional } \\
\text { escreening.it/sites/default/files/allegati/ } \\
\text { ONS_2015_full.pdf }\end{array}$ & 2015 \\
\hline $\begin{array}{l}\text { Spain (Cancer Strategy of National } \\
\text { Health System) }\end{array}$ & $\begin{array}{l}\text { http://www.msps.es/organizacion/ } \\
\text { sns/planCalidadSNS/pdf/Actualizacion } \\
\text { EstrategiaCancer.pdf }\end{array}$ & 2009 \\
\hline \multicolumn{3}{|l|}{ Cervical cancer } \\
\hline United States (USPSTF) & $\begin{array}{l}\text { https://www.uspreventiveservicestask } \\
\text { force.org/Page/Document/Update } \\
\text { SummaryFinal/cervical-cancer-screening }\end{array}$ & 2012 \\
\hline United States (ACS) & $\begin{array}{l}\text { https://www.cancer.org/cancer/ } \\
\text { cervical-cancer/prevention-and-early- } \\
\text { detection/cervical-cancer-screening- } \\
\text { guidelines.html }\end{array}$ & 2016 \\
\hline United States (ACOG) & $\begin{array}{l}\text { http://www.acog.org/Patients/FAQs/ } \\
\text { Cervical-Cancer-Screening }\end{array}$ & 2016 \\
\hline Luxembourg (Ministry of Health) & $\begin{array}{l}\text { https://plancancer.lu/about/depistage/ } \\
\text { cancer-du-col-de-luterus/depistage-- } \\
\text { actuel-cancer-du-col-de-luterus/ }\end{array}$ & \\
\hline Switzerland (League Against Cancer) & $\begin{array}{l}\text { https://www.liguecancer.ch/prevenir- } \\
\text { le-cancer/depistage-et-prevention- } \\
\text { du-cancer/cancer-du-col-de-luterus/ }\end{array}$ & 2010 \\
\hline
\end{tabular}


Table 6 The references of the national recommendations for breast, cervical, colorectal, prostate, skin, and lung cancer screening by country (Continued)

\begin{tabular}{|c|c|c|}
\hline Country & Reference & $\begin{array}{l}\text { Year of recommendation } \\
\text { or most recent update }\end{array}$ \\
\hline & $\begin{array}{l}\text { prevention-et-depistage-du-cancer- } \\
\text { du-col-de-luterus/ }\end{array}$ & \\
\hline Norway (Cancer Registry of Norway) & $\begin{array}{l}\text { https://www.kreftregisteret.no/en/ } \\
\text { screening/Cervical-Cancer-Screening- } \\
\text { Programme/ } \\
\text { https://www.kreftregisteret.no/global } \\
\text { assets/masseundersokelsen-mot- } \\
\text { livmorhalskreft/algoritme-hpv-test-i- } \\
\text { primarscreening-ny-april-2015.jpg }\end{array}$ & 2010 \\
\hline Netherlands (NIPHE) & $\begin{array}{l}\text { http://www.rivm.nl/en/Topics/C/ } \\
\text { Cervical_cancer_screening_programme }\end{array}$ & 2015 \\
\hline Germany (Federal Joint Committee) & $\begin{array}{l}\text { https:/wnw.g-ba.de/institution/themen } \\
\text { schwerpunkte/frueherkennung/krebs } \\
\text { frueherkennung/ }\end{array}$ & 2015 \\
\hline $\begin{array}{l}\text { Sweden (National Board of } \\
\text { Health and Welfare) }\end{array}$ & $\begin{array}{l}\text { http://www.socialstyrelsen.se/riktlinjer/ } \\
\text { nationellascreeningprogram/livmoder } \\
\text { halscancer-screeningme }\end{array}$ & 2014 \\
\hline Ireland (National Screening Service) & $\begin{array}{l}\text { http://www.screeningsenvice.ie/ } \\
\text { cervical.html }\end{array}$ & 2009 \\
\hline Austria (Austrian Cancer Aid Society) & $\begin{array}{l}\text { https:/wwww.krebshilfe.net/information/ } \\
\text { krebs-vorsorge/frauen/ }\end{array}$ & NR \\
\hline Denmark (National Board of Health) & $\begin{array}{l}\text { https:/www.sst.dk/da/udgivelser/2014/ } \\
\text { /media/31CB15B2A39E4A3EB198B9 } \\
\text { 486F66B4A2.ashx }\end{array}$ & 2014 \\
\hline Belgium (Foundation Against Cancer) & $\begin{array}{l}\text { http://www.cancer.be/les-cancers-types- } \\
\text { de-cancers-liste-z-cancer-du-col-de-lut- } \\
\text { rus/examens }\end{array}$ & 2017 \\
\hline Canada (CTFPHC) & $\begin{array}{l}\text { http://canadiantaskforce.ca/guidelines/ } \\
\text { published-guidelines/cervical-cancer/ }\end{array}$ & 2013 \\
\hline $\begin{array}{l}\text { Australia (Australian Government } \\
\text { Department of Health) }\end{array}$ & $\begin{array}{l}\text { http://www.cancerscreening.gov.au/ } \\
\text { internet/screening/publishing.nsf/ } \\
\text { Content/cervical-screening-1 }\end{array}$ & 2017 \\
\hline France (National Cancer Institute) & $\begin{array}{l}\text { http://www.e-cancer.fr/Professionnels- } \\
\text { de-sante/Depistage-et-detection- } \\
\text { precoce/Depistage-du-cancer-du- } \\
\text { col-de-l-uterus/Le-depistage-par- } \\
\text { frottis-cervico-uterin }\end{array}$ & 2017 \\
\hline Japan (National Cancer Center) & $\begin{array}{l}\text { http://canscreen.ncc.go.jp/guideline/ } \\
\text { shikyukeigan.html } \\
\text { http://canscreen.ncc.go.jp/guideline/ } \\
\text { shikyukeigan_eng.pdf }\end{array}$ & 2010 \\
\hline Iceland (Icelandic Cancer Society) & $\begin{array}{l}\text { https://www.krabb.is/leitarstod/um- } \\
\text { leitarstodina/af-hverju-leghalskrabbam } \\
\text { einsleit/spurningar-og-svor-um- } \\
\text { leghalskrabbameinsleit-1?Cache } \\
\text { Refresh=1 } \\
\text { https://www.krabb.is/english/ }\end{array}$ & NR \\
\hline UK (UK National Screening Committee) & $\begin{array}{l}\text { https://legacyscreening.phe.org.uk/ } \\
\text { cervicalcancer } \\
\text { http://www.nhs.uk/conditions/Cervical- } \\
\text { screening-test/Pages/Introduction.aspx }\end{array}$ & 2016 \\
\hline Finland (Cancer Society of Finland) & $\begin{array}{l}\text { https://www.cancer.fi/syoparekisteri/en/ } \\
\text { mass-screening-registry/cervical_ } \\
\text { cancer_screening/screening_programme/ } \\
\text { https://www.cancer.fi/syoparekisteri/en } \\
\text { /mass-screening-registry/cervical_ } \\
\text { cancer_screening/screening_ }\end{array}$ & 2010 \\
\hline
\end{tabular}


Table 6 The references of the national recommendations for breast, cervical, colorectal, prostate, skin, and lung cancer screening by country (Continued)

\begin{tabular}{|c|c|c|}
\hline Country & Reference & $\begin{array}{l}\text { Year of recommendation } \\
\text { or most recent update }\end{array}$ \\
\hline & $\begin{array}{l}\text { programme/new_screening_ } \\
\text { technologies/ }\end{array}$ & \\
\hline New Zealand (Ministry of Health) & $\begin{array}{l}\text { https://www.nsu.govt.nz/national- } \\
\text { cervical-screening-programme/about- } \\
\text { cervical-screening-programme }\end{array}$ & 2014 \\
\hline Italy (National Screening Observatory) & $\begin{array}{l}\text { http://www.osservatorionazionale } \\
\text { screening.it/sites/default/files/allegati/ } \\
\text { ONS_2015_full.pdf }\end{array}$ & 2015 \\
\hline $\begin{array}{l}\text { Spain (Cancer Strategy of National } \\
\text { Health System) }\end{array}$ & $\begin{array}{l}\text { http://www.msps.es/organizacion/sns/ } \\
\text { planCalidadSNS/pdf/Actualizacion } \\
\text { EstrategiaCancer.pdf }\end{array}$ & 2009 \\
\hline \multicolumn{3}{|l|}{ Colorectal cancer } \\
\hline $\begin{array}{l}\text { Australia (Australian Government } \\
\text { Department of Health) }\end{array}$ & $\begin{array}{l}\text { http://www.cancerscreening.gov.au/ } \\
\text { internet/screening/publishing.nsf/ } \\
\text { Content/bowel-screening-1 }\end{array}$ & 2016 \\
\hline Austria (Austrian Cancer Care) & $\begin{array}{l}\text { https://www.krebshilfe.net/information/ } \\
\text { krebs-vorsorge/frauen/ }\end{array}$ & N/A \\
\hline Belgium (Foundation Against Cancer) & $\begin{array}{l}\text { http///www.cancer.be/les-cancers/types- } \\
\text { de-cancers/cancer-du-gros-intestin- } \\
\text { colorectal/examens }\end{array}$ & 2017 \\
\hline $\begin{array}{l}\text { Canada (Canadian Task Force } \\
\text { on Preventive Health Care) }\end{array}$ & $\begin{array}{l}\text { https://canadiantaskforce.ca/guidelines/ } \\
\text { published-guidelines/colorectal-cancer/ }\end{array}$ & 2016 \\
\hline Denmark (National Board of Health) & $\begin{array}{l}\text { https:/www.sst.dk/da/udgivelser/2014/ } \\
\text { /media/31CB15B2A39E4A3EB198B94 } \\
\text { 86F66B4A2.ashx }\end{array}$ & 2014 \\
\hline Finland (Cancer Society of Finland) & $\begin{array}{l}\text { https://www.cancer.fi/@Bin/43261157 } \\
\text { /Sy\%C3\%B6p\%C3\%A4_Esite_Eng_- } \\
\text { Nettiin_080701.pdf }\end{array}$ & 2010 \\
\hline France (Institut National du Cancer) & $\begin{array}{l}\text { http://www.e-cancer.fr/Professionnels } \\
\text {-de-sante/Depistage-et-detection- } \\
\text { precoce/Depistage-du-cancer- } \\
\text { colorectal/Le-programme-de-depistage- } \\
\text { organise }\end{array}$ & 2015 \\
\hline Germany (Federal Joint Committee) & $\begin{array}{l}\text { https://www.g-ba.de/institution/ } \\
\text { themenschwerpunkte/frueher } \\
\text { kennung/ueberblick/ }\end{array}$ & 2017 \\
\hline Iceland (Icelandic Cancer Society) & $\begin{array}{l}\text { https://uww.krabb.is/media/milliforsida/ } \\
\text { RISTILKRABBAMEIN-Sunna-Gudlaugs } \\
\text { dottir.pdf }\end{array}$ & 2015 \\
\hline Ireland (National Screening Service) & $\begin{array}{l}\text { http://www.screeningservice.ie/bowel- } \\
\text { screening.html }\end{array}$ & 2012 \\
\hline Italy (National Screening Observatory) & $\begin{array}{l}\text { https://www.osservatorionazionale } \\
\text { screening.it/sites/default/files/allegati/ } \\
\text { ONS_2015_full.pdf }\end{array}$ & 2015 \\
\hline Japan (National Cancer Center) & $\begin{array}{l}\text { http://canscreen.ncc.go.jp/guideline/ } \\
\text { daicyougan.html }\end{array}$ & 2016 \\
\hline Luxembourg (Ministry of Health) & $\begin{array}{l}\text { https://plancancer.lu/about/depistage/ } \\
\text { cancer-colorectal/objectifs-plan-cancer/ }\end{array}$ & 2016 \\
\hline $\begin{array}{l}\text { Netherlands (National Institute for } \\
\text { Public Health and the Environment) }\end{array}$ & $\begin{array}{l}\text { http://www.rivm.nl/Onderwerpen/B/ } \\
\text { Bevolkingsonderzoek_darmkanker }\end{array}$ & 2014 \\
\hline New Zealand (Ministry of Health) & $\begin{array}{l}\text { http://www.health.govt.nz/our-work/ } \\
\text { diseases-and-conditions/cancer- } \\
\text { programme/bowel-cancer-programme/ } \\
\text { national-bowel-screening-programme }\end{array}$ & 2017 \\
\hline
\end{tabular}


Table 6 The references of the national recommendations for breast, cervical, colorectal, prostate, skin, and lung cancer screening by country (Continued)

\begin{tabular}{|c|c|c|}
\hline Country & Reference & $\begin{array}{l}\text { Year of recommendation } \\
\text { or most recent update }\end{array}$ \\
\hline & $\begin{array}{l}\text { https://www.kreftregisteret.no/en/ } \\
\text { screening/Screening-for-colorectal- } \\
\text { cancer/ }\end{array}$ & \\
\hline $\begin{array}{l}\text { Spain (Cancer Strategy of National } \\
\text { Health System) }\end{array}$ & $\begin{array}{l}\text { http://www.msps.es/organizacion/sns/ } \\
\text { planCalidadSNS/pdf/Actualizacion } \\
\text { EstrategiaCancer.pdf }\end{array}$ & 2009 \\
\hline $\begin{array}{l}\text { Sweden (National Board of } \\
\text { Health and Welfare) }\end{array}$ & $\begin{array}{l}\text { http://www.socialstyrelsen.se/riktlinjer/ } \\
\text { nationellascreeningprogram/tjock- } \\
\text { ochandtarmscancer-screen }\end{array}$ & 2014 \\
\hline Switzerland (League against Cancer) & $\begin{array}{l}\text { https://www.liguecancer.ch/prevenir- } \\
\text { le-cancer/depistage-et-prevention- } \\
\text { du-cancer/cancer-de-lintestin/ } \\
\text { programme-de-depistage-du-cancer- } \\
\text { de-lintestin/ }\end{array}$ & 2013 \\
\hline $\begin{array}{l}\text { United Kingdom (UK National } \\
\text { Screening Committee) }\end{array}$ & $\begin{array}{l}\text { https://www.gov.uk/government/ } \\
\text { uploads/system/uploads/attachment_ } \\
\text { data/file/538524/Screening_in_the_- } \\
\text { UK_making_effective_recommen } \\
\text { dations_2015_to_2016_180716_final.pdf }\end{array}$ & 2016 \\
\hline United States (American Cancer Society) & $\begin{array}{l}\text { https://www.cancer.org/cancer/colon- } \\
\text { rectal-cancer/detection-diagnosis- } \\
\text { staging/acs-recommendations.html }\end{array}$ & 2017 \\
\hline $\begin{array}{l}\text { United States (American College of } \\
\text { Gastroenterology) }\end{array}$ & $\begin{array}{l}\text { http://gi.org/wp-content/uploads/ } \\
\text { 2017/06/ajg2017174a.pdf }\end{array}$ & 2017 \\
\hline $\begin{array}{l}\text { United States (U.S. Preventive } \\
\text { Services Task Force) }\end{array}$ & $\begin{array}{l}\text { https://www.uspreventiveservicestask } \\
\text { force.org/Page/Document/Recommen } \\
\text { dationStatementFinal/colorectal-cancer } \\
\text {-screening2\#tab }\end{array}$ & 2016 \\
\hline \multicolumn{3}{|l|}{ Prostate cancer } \\
\hline $\begin{array}{l}\text { Australia (Australian Government } \\
\text { Department of Health) }\end{array}$ & $\begin{array}{l}\text { http://www.cancerscreening.gov.au/ } \\
\text { internet/screening/publishing.nsf/ } \\
\text { Content/prostate-cancer-screening }\end{array}$ & 2017 \\
\hline Austria (Austrian Cancer Care) & $\begin{array}{l}\text { https://www.krebshilfe.net/informa } \\
\text { tion/krebs-vorsorge/maenner/ }\end{array}$ & 2015 \\
\hline Belgium (Foundation Against Cancer) & $\begin{array}{l}\text { http://www.cancer.be/les-cancers/ } \\
\text { types-de-cancers/cancer-de-la- } \\
\text { prostate/examens }\end{array}$ & 2017 \\
\hline $\begin{array}{l}\text { Canada (Canadian Task Force on } \\
\text { Preventive Health Care) }\end{array}$ & $\begin{array}{l}\text { https://canadiantaskforce.ca/guide } \\
\text { lines/published-guidelines/prostate } \\
\text {-cancer/ }\end{array}$ & 2014 \\
\hline Denmark (National Board of Health) & $\begin{array}{l}\text { No available recommendations } \\
\text { concerning prostate cancer }\end{array}$ & \\
\hline Finland (Cancer Society of Finland) & $\begin{array}{l}\text { No available recommendations } \\
\text { concerning prostate cancer }\end{array}$ & \\
\hline France (Institut National du Cancer) & $\begin{array}{l}\text { http://www.e-cancer.fr/Professionnels } \\
\text {-de-sante/Depistage-et-detection- } \\
\text { precoce/Depistage-du-cancer-de-la- } \\
\text { prostate }\end{array}$ & 2016 \\
\hline Germany (Federal Joint Committee) & $\begin{array}{l}\text { https://www.g-ba.de/institution/ } \\
\text { themenschwerpunkte/frueherken } \\
\text { nung/ueberblick/ }\end{array}$ & 2017 \\
\hline Iceland (Icelandic Cancer Society) & $\begin{array}{l}\text { https://www.krabb.is/fraedsla-forvarnir } \\
\text { /krabbamein-a-o/blodruhalskirtilskra } \\
\text { bbamein/ }\end{array}$ & 2016 \\
\hline Ireland (National Screening Service) & $\begin{array}{l}\text { No available recommendations } \\
\text { concerning prostate cancer }\end{array}$ & \\
\hline
\end{tabular}


Table 6 The references of the national recommendations for breast, cervical, colorectal, prostate, skin, and lung cancer screening by country (Continued)

\begin{tabular}{|c|c|c|}
\hline Country & Reference & $\begin{array}{l}\text { Year of recommendation } \\
\text { or most recent update }\end{array}$ \\
\hline Italy (National Screening Observatory) & $\begin{array}{l}\text { No available recommendations } \\
\text { concerning prostate cancer }\end{array}$ & \\
\hline Japan (National Cancer Center) & $\begin{array}{l}\text { http://canscreen.ncc.go.jp/guideline/ } \\
\text { zenritsusengan.html }\end{array}$ & 2009 \\
\hline Luxembourg (Ministry of Health) & $\begin{array}{l}\text { https://plancancer.lu/about/depistage/ } \\
\text { cancer-de-la-prostate/ }\end{array}$ & 2014 \\
\hline $\begin{array}{l}\text { Netherlands (National Institute for Public } \\
\text { Health and the Environment) }\end{array}$ & $\begin{array}{l}\text { No available recommendations } \\
\text { concerning prostate cancer }\end{array}$ & \\
\hline New Zealand (Ministry of Health) & $\begin{array}{l}\text { http://www.health.govt.nz/our-work/ } \\
\text { diseases-and-conditions/cancer-prog } \\
\text { ramme/prostate-cancer-programme }\end{array}$ & 2016 \\
\hline Norway (Cancer Registry of Norway) & $\begin{array}{l}\text { No available recommendations concer } \\
\text { ning prostate cancer }\end{array}$ & \\
\hline $\begin{array}{l}\text { Spain (Cancer Strategy of } \\
\text { National Health System) }\end{array}$ & $\begin{array}{l}\text { http://www.msps.es/organizacion/ } \\
\text { sns/planCalidadSNS/pdf/Actualizacion } \\
\text { EstrategiaCancer.pdf }\end{array}$ & 2009 \\
\hline $\begin{array}{l}\text { Sweden (National Board of } \\
\text { Health and Welfare) }\end{array}$ & $\begin{array}{l}\text { http://www.socialstyrelsen.se/riktlinjer/ } \\
\text { nationellascreeningprogram/prostata } \\
\text { cancer-screeningmedpsa }\end{array}$ & 2016 \\
\hline Switzerland (League against Cancer) & $\begin{array}{l}\text { https://www.liguecancer.ch/prevenir- } \\
\text { le-cancer/depistage-et-prevention-du } \\
\text {-cancer/depistage-du-cancer-de-la- } \\
\text { prostate/ }\end{array}$ & 2015 \\
\hline $\begin{array}{l}\text { United Kingdom (UK National } \\
\text { Screening Committee) }\end{array}$ & $\begin{array}{l}\text { https://www.gov.uk/government/ } \\
\text { uploads/system/uploads/attachment_ } \\
\text { data/file/538524/Screening_in_the__ } \\
\text { UK_making_effective_recommen } \\
\text { dations_2015_to_2016_180716__ } \\
\text { final.pdf }\end{array}$ & 2016 \\
\hline United States (American Cancer Society) & $\begin{array}{l}\text { https://www.cancer.org/cancer/ } \\
\text { prostate-cancer/early-detection/acs- } \\
\text { recommendations.html }\end{array}$ & 2016 \\
\hline United States (American Urological Association) & $\begin{array}{l}\text { https://www.auanet.org/guidelines/ } \\
\text { early-detection-of-prostate-cancer- } \\
\text { (2013-reviewed-and-validity-confir } \\
\text { med-2015) }\end{array}$ & 2015 \\
\hline $\begin{array}{l}\text { United States (U.S. Preventive } \\
\text { Services Task Force) }\end{array}$ & $\begin{array}{l}\text { https://www.uspreventiveservices } \\
\text { taskforce.org/Page/Document/Update } \\
\text { SummaryFinal/prostate-cancer- } \\
\text { screening }\end{array}$ & 2012 \\
\hline \multicolumn{3}{|l|}{ Skin cancer } \\
\hline United States (USPSTF) & $\begin{array}{l}\text { https://www.uspreventiveservicestask } \\
\text { force.org/Page/Document/Update } \\
\text { SummaryFinal/skin-cancer-screening2 }\end{array}$ & 2016 \\
\hline United States (ACS) & $\begin{array}{l}\text { https://www.cancer.org/cancer/skin- } \\
\text { cancer/prevention-and-early-detection/ } \\
\text { skin-exams.html }\end{array}$ & 2016 \\
\hline Germany (Federal Joint Committee) & $\begin{array}{l}\text { https://www.g-ba.de/institution/ } \\
\text { themenschwerpunkte/frueher } \\
\text { kennung/krebsfrueherkennung/ }\end{array}$ & 2017 \\
\hline Austria (Austrian Cancer Aid Society) & $\begin{array}{l}\text { https://www.krebshilfe.net/information/ } \\
\text { krebs-vorsorge/frauen/ }\end{array}$ & NA \\
\hline France (National Cancer Institute) & $\begin{array}{l}\text { http://www.e-cancer.fr/Professionnels- } \\
\text { de-sante/Depistage-et-detection- } \\
\text { precoce/Detection-precoce-des- }\end{array}$ & 2016 \\
\hline
\end{tabular}


Table 6 The references of the national recommendations for breast, cervical, colorectal, prostate, skin, and lung cancer screening by country (Continued)

\begin{tabular}{|c|c|c|}
\hline Country & Reference & $\begin{array}{l}\text { Year of recommendation } \\
\text { or most recent update }\end{array}$ \\
\hline & $\begin{array}{l}\text { cancers-de-la-peau/Aide-pour-votre- } \\
\text { pratique }\end{array}$ & \\
\hline \multicolumn{3}{|l|}{ Lung cancer } \\
\hline United States (USPSTF) & $\begin{array}{l}\text { https://www.uspreventiveservicestask } \\
\text { force.org/Page/Document/Update } \\
\text { SummaryFinal/lung-cancer-screening }\end{array}$ & 2013 \\
\hline United States (ACS) & $\begin{array}{l}\text { https://www.cancer.org/health-care- } \\
\text { professionals/american-cancer-society- } \\
\text { prevention-early-detection-guidelines/ } \\
\text { lung-cancer-screening-guidelines.html }\end{array}$ & 2013 \\
\hline Canada (CTFPHC) & $\begin{array}{l}\text { http://canadiantaskforce.ca/guidelines/ } \\
\text { published-guidelines/lung-cancer/ }\end{array}$ & 2016 \\
\hline $\begin{array}{l}\text { Australia (Australian Government } \\
\text { Department of Health) }\end{array}$ & $\begin{array}{l}\text { http://www.cancerscreening.gov.au/ } \\
\text { internet/screening/publishing.nsf/ } \\
\text { Content/lung-cancer-screening }\end{array}$ & 2015 \\
\hline Japan (National Cancer Center) & $\begin{array}{l}\text { http://canscreen.ncc.go.jp/guideline/ } \\
\text { haigan.html }\end{array}$ & NA \\
\hline UK (UK National Screening Committee) & $\begin{array}{l}\text { https://legacyscreening.phe.org.uk/ } \\
\text { lungcancer }\end{array}$ & 2006 \\
\hline
\end{tabular}

\section{Acknowledgements}

Dr. Roland Grad (Magill University, Montreal, Canada) and Dr. Kenneth W. Lin (Georgetown University, Washington, DC) provided feedback and comments on a final draft of the manuscript.

\section{Funding}

This project was unfunded.

\section{Availability of data and materials}

Not applicable

\section{Authors' contributions}

MHE conceptualized and led the project. TNT and KIR abstracted the data and created the tables, and also wrote the first drafts of the "Introduction," "Methods," and "Results" sections. These were edited by MHE, who also reviewed the data abstraction for accuracy and wrote the "Discussion" section. All authors read and approved the final manuscript.

\section{Ethics approval and consent to participate}

Not applicable

\section{Consent for publication}

Not applicable

\section{Competing interests}

The authors declare that they have no competing interests.

\section{Publisher's Note}

Springer Nature remains neutral with regard to jurisdictional claims in published maps and institutional affiliations.

\section{Author details}

${ }^{1}$ College of Public Health, University of Georgia, 125 Miller Hall, UGA Health Sciences, GA 30602 Athens, Georgia, USA.

2Department of Pharmaceutical Outcomes and Policy, College of Pharmacy, University of Florida, Gainesville, Florida, USA. ${ }^{3}$ Augusta University/University of Georgia Medical Partnership Campus, Athens, Georgia, USA.

Received: 17 August 2017 Accepted: 12 January 2018

Published online: 02 March 2018

\section{References}

1. WHO. Global Health Estimates 2015: deaths by cause, age, sex, by country and by region, 2000-2015. 2016; Available from: http://www.who.int/healthinfo/global_burden_disease/estimates/en/index1.html. 
2. Ferlay J, et al. Cancer incidence and mortality worldwide: sources, methods and major patterns in GLOBOCAN 2012. Int J Cancer. 2015;136(5):E359-86.

3. International Agency for Research on Cancer., Cancer screening in the European Union (2017): report on the implementatation of the council recommendation on cancer screening. 2017.

4. International Agency for Research on Cancer. IARC handbooks of cancer prevention volume 10: cervix cancer screening. Lyon: IARC; 2005.

5. Siu AL. Screening for breast cancer: U.S. Preventive Services Task Force Recommendation statement. Ann Intern Med. 2016;164(4):279-96.

6. Moyer VA. Screening for cervical cancer: U.S. Preventive Services Task Force recommendation statement. Ann Intern Med. 2012;156(12):880-91. w312

7. Moyer VA. Screening for lung cancer: U.S. Preventive Services Task Force recommendation statement. Ann Intern Med. 2014;160(5):330-8.

8. Force, U.S.P.S.T, et al. Screening for colorectal cancer: US Preventive Services Task Force recommendation statement. JAMA. 2016;315(23):2564-75.

9. Schreuders EH, et al. Colorectal cancer screening: a global overview of existing programmes. Gut. 2015; 64(10):1637-49.

10. WHO. Guidelines approved by the guidelines review committee. In: WHO Guidelines for Screening and Treatment of Precancerous Lesions for Cervical Cancer Prevention. 2013, World Health Organization copyright (c). Geneva: World Health Organization; 2013.

11. WHO. WHO position paper on mammography screening. Geneva: World Health Organization; 2014. Available from: http://apps.who.int/iris/bitstream/10665/137339/1/9789241507936_eng.pdf?ua=1\&ua=1. [cited 2017 June 09]

12. Berry DA, et al. Effect of screening and adjuvant therapy on mortality from breast cancer. N Engl J Med. 2005; 353(17):1784-92.

13. Lauby-Secretan B, et al. Breast-cancer screening —viewpoint of the IARC Working Group. N Engl J Med. 2015; 372(24):2353-8.

14. Olson B, et al. Cervical cancer screening programs and guidelines in low- and middle-income countries. Int J Gynaecol Obstet. 2016;134(3):239-46.

15. Bacchus CM, et al. Recommendations on screening for colorectal cancer in primary care. CMAJ. 2016;188(5):340-8

16. Development, O.f.E.C.a. Health expenditure and financing. OECD Statistics; Available from: http://stats.oecd.org/ Index.aspx?DataSetCode=SHA. Accessed Feb 2018.

17. Rex DK, et al. Colorectal cancer screening: recommendations for physicians and patients from the U.S. MultiSociety Task Force on Colorectal cancer. Am J Gastroenterol. 2017;112(7):1016-30.

18. Field JK, et al. The UK Lung Cancer Screening Trial: a pilot randomised controlled trial of low-dose computed tomography screening for the early detection of lung cancer. Health Technol Assess. 2016;20(40):1-146.

19. Paci $E$, et al. Mortality, survival and incidence rates in the ITALUNG randomised lung cancer screening trial. Thorax 2017;72(9):825-31.

20. Owens DK, et al. Use of decision models in the development of evidence-based clinical preventive services recommendations: methods of the U.S. Preventive Services Task Force. Ann Intern Med. 2016;165(7):501-8.

21. Wallace $E$, et al. The epidemiology of malpractice claims in primary care: a systematic review. BMJ Open. 2013;3(7): e002929.

22. Bleyer A, Welch HG. Effect of three decades of screening mammography on breast-cancer incidence. $\mathrm{N}$ Engl J Med. 2012;367(21):1998-2005.

23. Lenzer J, et al. Ensuring the integrity of clinical practice guidelines: a tool for protecting patients. BMJ. 2013;347:f5535.

24. Institute of Medicine. Clinical practice guidelines we can trust. Washington, D.C.: The National Academies Press; 2011.

\section{Submit your next manuscript to BioMed Central and we will help you at every step:}

- We accept pre-submission inquiries

- Our selector tool helps you to find the most relevant journal

- We provide round the clock customer support

- Convenient online submission

- Thorough peer review

- Inclusion in PubMed and all major indexing services

- Maximum visibility for your research

Submit your manuscript at www.biomedcentral.com/submit 